\title{
Lentiviral Hematopoietic Stem Cell Gene Therapy in Inherited Immune and Lysoso- mal Enzyme Deficiencies
}

\begin{abstract}
Gerard Wagemaker*
Erasmus University Rotterdam, The Netherlands; Center for Stem Cell Research and Development, Hacettepe University, Ankara, Turkey; Raisa Gorbacheva Memorial Institute of Children Oncology, Hematology and Transplantation, St. Petersburg, Russia
\end{abstract}

Gerard Wagemaker, PhD, Professor, Erasmus University Rotterdam, c/o PO Box 37048

3005 LA Rotterdam, The Netherlands
Phone: +31-6-51619585

E-mail: g.wagemaker@genetherapy.nl

\section{Summary}

Rare diseases affect millions of people worldwide. Many of those are inherited disorders resulting in chronic disability and requiring cost-intensive care. Hematopoietic stem cell gene therapy has been developed over more than 20 years. At the state of the art, gene therapy is within reach for diseases in which (i) the genetic defect is identified, (ii) the diagnosis is made sufficiently early for a meaningful therapeutic intervention, (iii) a specific animal model is available for efficacy and safety evaluation. Appropriate therapeutic transgenes should also comply with certain biological criteria. Third-generation lentiviral vectors have been made self-inactivating (SIN) by deletion of enhancer regions from the LTR sequences thus reducing the risk of influencing nearby genes, resulting in favorable safety profiles. At the present time, lentiviral hematopoietic stem cell gene therapy has entered the stage of initial clinical implementation for immune deficiencies and lysosomal storage disorders. We discuss initial clinical trials using these vectors for selected metabolic storage disorders, which include adrenoleukodystrophy, metachromatic leukodystrophy, Hurler (MPS I), Pompe (GSD II), and Fabry diseases. This brief review summarizes the development and current clinical implementation of these approaches.

\section{Keywords}

Hematopoietic stem cells, lentivirus vector, gene therapy, inherited immune deficiencies, lysosomal diseases.

\section{Introduction}

Rare diseases, of which $80 \%$ are inherited disorders, affect some $6 \%$ of the human population, amounting in Europe to around 30 million people. Since many result in chronic disability and cost-intensive care, the impact is disproportional and may well be over $20 \%$ of health care costs, although the current lack of registration, contrary to cancer, makes exact estimates difficult. Most of the approximately 7500 known inherited diseases lack a curative intervention, are managed by symptomatic treatment and, in case of a family history, by prenatal diagnosis. A small minority is included in newborn screening programs. At the state of the art, gene therapy is within reach for diseases in which (i) the genetic defect is identified, (ii) the diagnosis is made sufficiently early for a meaningful therapeutic intervention, (iii) a specific animal model is available for efficacy and safety evaluation, (iv) strict regulation of transgene product levels is not required, (v) the transgene produces levels sufficient for sustained alleviation of symptoms or cure, and (vi) adverse immune responses to the transgene product are not expected, do not interfere with efficacy, or can be successfully counteracted or circumvented. Many of the more than 100 primary immune deficiencies and around 40 lysosomal storage disorders meet those criteria.

This brief review covers development and prospect of gene therapy for inherited immune deficiencies and lysosomal storage disorders, extending an earlier review [45].

\section{Initial development of hematopoi- etic stem cell gene therapy}

Hematopoietic stem cell gene therapy has been developed over more than 20 years. The pioneering trials for X-linked severe combined immune deficiency (SCID) using gammaretroviral gene transfer vectors resulted in successful restoration of $\mathrm{T}$ cell immunity $[17,22]$ in 18 patients and in 
long-term survival for 17 patients out of 20, a survival rate similar to HLA-identical BM transplantation [35]. Unfortunately, in 5 patients autonomous $\mathrm{T}$ cell clones developed into leukemia, among which 1 patient did not survive. In the context of European collaborative projects, the pathogenesis was rapidly elucidated, resulting in a series of publications on mechanisms involved in gammaretroviral mutagenesis and oncogenesis [3,12,13,28,31,32,37]. Briefly, gammaretroviral vectors generally integrate near the transcription start sites of expressed genes with a preference for proto-oncogenes, which results in aberrant expression driven by the promoter/ enhancer of the therapeutic transgene and may result in a preleukemic state. It is not excluded that the phenotypes of the treated diseases co-predispose to leukemia development [38], given the absence of leukemia in the ADA-SCID trial $[1,4]$, a $25 \%$ incidence in the X-linked SCID trials and an over $75 \%$ incidence in a gammaretroviral Wiskott-Aldrich trial [6].

\section{Development of lentiviral vector gene therapy in inherited storage disorders}

The gammaretroviral vectors have been replaced by HIV-1 derived lentiviral vectors $[29,36,48]$, which lack the propensity for integration near proto-oncogenes and have the added advantage of integrating into quiescent cells, such as longterm repopulating stem cells. In addition, third generation lentiviral vectors made self-inactivating (SIN) by deletion of enhancer regions from the long terminal repeat sequences reduce the risk of influencing nearby genes, resulting in favorable safety profiles [8]. Systematic disease specific efficacy and safety evaluations, including codon optimization and careful promoter selection have enabled initial clinical trials using these vectors for selected metabolic storage disorders (Table 1), which include adrenoleukodystrophy (ALD), metachromatic leukodystrophy (MLD), and Hurler (MPS I), Pompe (GSD II) and Fabry diseases. We have focused on
Pompe disease, the only disorder so far developed for stem cell gene therapy [42] in which allogeneic stem cell transplantation has not been applied due to lack of enzyme expression in the hematopoietic system [25] and in addition studied stem cell gene therapy for Hurler syndrome.

\section{Hurler Syndrome and Pompe disease}

Hurler Syndrome (Mucopolysaccharidosis type I, OMIM \# 252800) is a lethal autosomal recessive storage disorder caused by a deficiency of the lysosomal enzyme $a$-L-iduronidase (IDUA; EC 3.2.1.76). The deficiency leads to insufficient degradation of glycoaminoglycans (GAG's') that interferes with normal cellular function and causes a multisystem disorder affecting the CNS, liver, skeleton, lungs and sensory organs (corneal clouding and deafness), average expected life-span approximately 5-10 years. Treatment consists of alloSCT, currently the only therapeutic option to establish long-term survival and protection of the CNS. Enzyme replacement has a systemic effect but does not reach the brain or the skeletal bones. AlloSCT does not improve the skeleton pathology either. Although clinical outcome of SCT has improved by the use of umbilical cord stem cells, progressive bone disease persists, leading to severe handicaps. An international long term clinical follow-up cohort of Hurler patients treated with alloSCT including $>80 \%$ of the patients successfully transplanted worldwide [2] showed that certain genotypes, age at HSCT, and poor performance at HSCT are predictors for poor skeletal and neurodevelopmental outcome. These findings warrant the development of a single curative gene therapy approach.

Pompe disease (glycogen storage disease type II, acid maltase deficiency, OMIM \# 232300) is a rare autosomal recessive lysosomal storage disorder caused by mutations in the gene-encoding acid $\alpha$-glucosidase (EC 3.2.1.20) [40]. Severe mutations cause complete enzyme deficiency, resulting in the classic infantile form of Pompe disease, which was first

Table 1. Hematopoietic stem cell gene therapy for metabolic storage disorders

\begin{tabular}{|c|c|c|}
\hline Disorder & Deficient gene/enzyme & References \\
\hline $\begin{array}{l}\text { In clinical trial } \\
\text { Adrenoleukodystrophy } \\
\text { Metachromatic leukodystrophy }\end{array}$ & $\begin{array}{l}A B C D 1 \\
\text { arylsulfatase A }\end{array}$ & $\begin{array}{l}\text { Cartier et al., } 2009 \\
\text { Biffi et al., } 2013\end{array}$ \\
\hline $\begin{array}{l}\text { Preparing for clinical trial } \\
\text { Hurler syndrome (MPS I) } \\
\text { Pompe disease (GSD II) } \\
\text { Fabry disease }\end{array}$ & $\begin{array}{l}\alpha \text {-iduronidase } \\
\text { acid } \alpha \text {-glucosidase } \\
\alpha \text {-galactosidase A }\end{array}$ & $\begin{array}{l}\text { Visigalli et al., 2010, } 2016 \\
\text { van Til, Wagemaker, } 2014 \\
\text { Yoshimitsu et al., } 2007\end{array}$ \\
\hline $\begin{array}{l}\text { Preclinical efficacy and safety evalu- } \\
\text { ation in progress } \\
\text { Krabbe disease } \\
\text { (globoid cell leukodystrophy) } \\
\text { Farber disease } \\
\text { Gaucher disease }\end{array}$ & $\begin{array}{l}\text { galactosylceramidase } \\
\text { ceramidase } \\
\text { glucocerebrosidase }\end{array}$ & $\begin{array}{l}\text { Gentner et al., } 2010 \\
\text { Walia et al., } 2011 \\
\text { Enquist et al., } 2006\end{array}$ \\
\hline
\end{tabular}


described by the Dutch pathologist J.C.Pompe [33]. Symptoms are caused by glycogen accumulation, mainly in skeletal, cardiac and smooth muscle, but also in other tissues, including the central and peripheral nervous system. In the first months of life, patients present with progressive muscle weakness, hypertrophic cardiomyopathy, respiratory problems and feeding difficulties. If untreated, this leads to death before the age of one year [39]. Older children and adults may have up to $20-30 \%$ residual enzyme activity and show a more slowly progressive phenotype. The symptoms generally result from weakness of the (proximal) skeletal muscles. These patients eventually become wheelchair bound and ventilator dependent in late childhood or adulthood.

Enzyme replacement therapy (ERT) by administration of recombinant acid $\alpha$-glucosidase [16,40] (Myozyme ${ }^{\circledR}$ ) is currently the only effective treatment, requiring high dose biweekly administration. Although of considerable benefit to many patients, ERT is not curative, requires life-long administration, may result in immune responses to the recombinant enzyme [41] and, partly due to the high doses required for clinical efficacy, the costs are extremely high. Therefore, a corrective intervention with curative intent represents an unmet medical need.

\section{Efficacy and safety evaluation of lentiviral vector gene therapy in the Hurler and Pompe mouse models}

The natural course of Hurler's disease is invalidating and lethal, and the drawbacks of the current therapeutic modalities justify a gene therapy approach. An IDUA knock-out mouse model has been developed suitable to study gene therapeutic approaches and made available to our research. A gene therapy study with HSC in the IDUA KO mice showed improvement of disease pathology, including the brain, but bone remodeling was not reported [14]. Using a codon optimized IDUA gene driven by a cellular promoter in a lentiviral vector to transduce hematopoietic stem cells, we demonstrated long-term expression in the hematopoietic system resulting in full correction of the Hurler phenotype (unpublished) without any severe adverse effects. Similar re- sults and a further safety analysis were obtained in a parallel study $[43,44]$, completing the preclinical analysis enabling an initial clinical trial in selected patients.

In the initial evaluation of lentiviral stem cell gene therapy for Pompe disease using an efficient overnight transduction protocol [42], we demonstrated that approximately $30 \%$ successfully transduced cells present in the bone marrow after sublethal total body irradiation as conditioning for transplantation resulted in high levels of a-glucosidase. Restoration of a-glucosidase activity in target tissues by uptake through the mannose-6-phosphate receptor reduced glycogen storage proportional to the enzyme levels achieved, with full correction of glycogen storage in liver and spleen, correction of the life-threatening cardiomyopathy, significantly improved respiration and improved, but not fully normalized skeletal muscle function. Of particular interest was the demonstration of robust immune tolerance to the recombinant transgene product. In the follow-up study (manuscript in preparation), codon-optimization of the therapeutic transgene resulted in full correction of the phenotype including skeletal muscles. Remarkably, although Pompe disease does not result in mental retardation or other neuronal problems, also brain glycogen levels normalized entirely, with all astrocytes, which play a key role in glycogen storage and glycogenolysis in the brain, showing active acid a-glucosidase activity. Apparently the microglia descendants of hematopoietic stem cells, which are capable of passing the blood-brain-barrier, as we originally demonstrated in the mouse model of Krabbe disease [24], provide sufficient acid a-glucosidase to normalize glycogen levels also in neuronal tissue. Up till now, hematopoietic stem cell gene therapy is the only approach to achieve both robust immune tolerance to the transgene product and efficacy in bypassing the blood/ brain barrier, as has also been observed by others [43].

\section{Clinical implementation of stem cell gene therapy in primary im- mune deficiencies}

A summary of the current developments is provided in Table 2. Briefly, successful clinical trials are ongoing for X-linked SCID, ADA-SCID and Wiskott-Aldrich syndrome, while

Table 2. Hematopoietic stem cell gene therapy for inherited immune deficiencies

\begin{tabular}{|c|c|c|}
\hline Disorder & Deficient gene/protein & References \\
\hline $\begin{array}{l}\text { In clinical trial } \\
\text { SCID-X1 } \\
\text { ADA-SCID } \\
\text { Wiskott-Aldrich Syndrome }\end{array}$ & $\begin{array}{l}\text { IL2-RG } \\
\text { Adenosine deaminase } \\
\text { WASP }\end{array}$ & $\begin{array}{l}\text { Gaspar et al., 2011a; Hacein-Bey-Abina et al., } 2014 \\
\text { Gaspar et al., 2011b; Cicalese et al., } 2016 \\
\text { Pala et al., } 2015\end{array}$ \\
\hline $\begin{array}{l}\text { Preparing for clinical trial } \\
\text { Chronic Granulomatous Disease } \\
\text { RAG2 deficiency } \\
\text { Artemis }\end{array}$ & $\begin{array}{l}\text { gp91phox } \\
\text { RAG-2 } \\
\text { Artemis }\end{array}$ & $\begin{array}{l}\text { Kaufmann et al., 2014; De Ravin et al., } 2016 \\
\text { van Til, Wagemaker, } 2014 \\
\text { Rivera-Munoz et al., } 2016\end{array}$ \\
\hline
\end{tabular}


clinical trials are being prepared for RAG2 deficiency, chronic granulomatous disease and Artemis. Gene therapy for ADA-SCID, which is difficult to treat with allogeneic stem cell transplantation, has recently been registered as an advanced therapy medicinal product and will soon be considered as the standard treatment for this disease.

\section{Further developments}

The future development of stem cell gene therapy efficacy and safety would obviously benefit considerably from non-cytoreductive preparation of the patients to enable engraftment of the gene-corrected cells, ex vivo stem cell expansion both to promote engraftment of transduced cells and to enable selection of stem cells for transplantation, lineage specific expression of the therapeutic transgene, targeted gene delivery, and eventually gene editing of the deficient mutant genes. Promoting engraftment by temporary mobilization of endogenous stem cells to open the stem cell niches in the bone marrow has been proposed [9] and applied successfully in the X-SCID mouse model [26]. An initial success has recently been reported in gene editing [20]. If the current clinical trials using lentiviral stem cell gene transfer prove efficacious and safe, its rapid clinical implementation in a variety of eligible inherited disorders will become within reach in the interest of the patients involved and thereby of health care and its costs.

\section{Funding}

Funding was provided by the European Commission's 5th, 6th and 7th Framework Programs, Contracts QLK3-CT2001-00427-INHERINET, LSHB-CT-2004-005242-CONSERT, LSHB-CT-2006-19038-Magselectofection, Grant Agreement 222878-PERSIST and Grant agreement 261387 CELL-PID, and by the Netherlands Health Research and Development Organization ZonMW (Translational Gene Therapy program grants 43100016 and 43400010 ).

\section{Author Disclosure Statement}

The author declares no competing financial interest.

\section{References}

1. Aiuti A, Cassani B, Andolfi G, Mirolo M, Biasco L, Recchia A, Urbinati F, Valacca C, Scaramuzza S, Aker M, Slavin S, Cazzola M, Sartori D, Ambrosi A, Di Serio C, Roncarolo MG, Mavilio F, Bordignon C. Multilineage hematopoietic reconstitution without clonal selection in ADA-SCID patients treated with stem cell gene therapy. J Clin Invest 2007; 117 (8): 2233-2240.

2. Aldenhoven M, Wynn RF, Orchard PJ, O’Meara A, Veys P, Fischer A,Valayannopoulos V, Neven B, Rovelli A, Prasad VK, Tolar J, Allewelt H, Jones SA, Parini R, Renard M, Bordon V, Wulffraat NM, de Koning TJ, Shapiro EG, Kurtzberg J, Boelens JJ. Long-term outcome of Hurler syndrome patients after hematopoietic cell transplantation: an international multicenter study. Blood 2015; 125 (13): 2164-2172.
3. Baum C, von Kalle C, Staal FJ, Li Z, Fehse B, Schmidt M, Weerkamp F, Karlsson S, Wagemaker G, Williams DA. Chance or necessity? Insertional mutagenesis in gene therapy and its consequences. Mol Ther 2004; 9 (1): 5-13.

4. Biasco L, Ambrosi A, Pellin D, Bartholomae C, Brigida I, Roncarolo MG, Di Serio C, von Kalle C, Schmidt M, Aiuti A. Integration profile of retroviralvector in gene therapy treated patients is cell-specific according to gene expression and chromatin conformation of target cell. EMBO Mol Med 2011; 3 (2): 89-101.

5. Biffi A, Montini E, Lorioli L, Cesani M, Fumagalli F, Plati T, Baldoli C, Martino S, Calabria A, Canale S, Benedicenti F, Vallanti G, Biasco L, Leo S, Kabbara N, Zanetti G, Rizzo WB, Mehta NA, Cicalese MP, Casiraghi M, Boelens JJ, Del Carro U, Dow DJ, Schmidt M, Assanelli A, Neduva V, Di Serio C, Stupka E, Gardner J, von Kalle C, Bordignon C, Ciceri F, Rovelli A, Roncarolo MG, Aiuti A, Sessa M, Naldini L. Lentiviral hematopoietic stem cell gene therapy benefits metachromatic leukodystrophy. Science 2013;341(6148):1233158.

6. Braun CJ, Boztug K, Paruzynski A, Witzel M, Schwarzer A, Rothe M, Modlich U, Beier R, Göhring G, Steinemann D, Fronza R, Ball CR, Haemmerle R, Naundorf S, Kühlcke K, Rose M, Fraser C, Mathias L, Ferrari R, Abboud MR, AlHerz W, Kondratenko I, Maródi L, Glimm H, Schlegelberger B, Schambach A, Albert MH, Schmidt M, von Kalle C, Klein C. Gene therapy for Wiskott-Aldrichsyndrome-longterm efficacy and genotoxicity. Sci Transl Med 2014; 6 (227): $227 \mathrm{ra3} 3$.

7. Hematopoietic stem cell gene therapy with a lentiviral vector in X-linked adrenoleukodystrophy.Cartier N, Hacein-Bey-Abina S, Bartholomae CC, Veres G, Schmidt M, Kutschera I, Vidaud M, Abel U, Dal-Cortivo L, Caccavelli L, Mahlaoui N, Kiermer V, Mittelstaedt D, Bellesme C, Lahlou N, Lefrère F, Blanche $S$, Audit $M$, Payen E, Leboulch P, l'Homme B, Bougnères $\mathrm{P}$, Von Kalle $\mathrm{C}$, Fischer A, Cavazzana-Calvo M, Aubourg P. Science 2009; 326 (5954): 818-823.

8. Cesana D, Ranzani M, Volpin M, Bartholomae C, Duros C, Artus A, Merella S, Benedicenti F, Sergi Sergi L, Sanvito F, Brombin C, Nonis A, Serio CD, Doglioni C, von Kalle C, Schmidt M, Cohen-Haguenauer O, Naldini L, Montini E. Uncovering and dissecting the genotoxicity of self-inactivating lentiviral vectors in vivo. Mol Ther 2014; 22 (4): 774-785.

9. Chen J, Larochelle A, Fricker S, Bridger G, Dunbar CE, Abkowitz JL. Mobilization as a preparative regimen for hematopoietic stem cell transplantation. Blood 2006; 107 (9): 3764-3771.

10. Cicalese MP, Ferrua F, Castagnaro L, Pajno R, Barzaghi F, Giannelli S, Dionisio F, Brigida I, Bonopane M, Casiraghi M, Tabucchi A, Carlucci F, Grunebaum E, Adeli M, Bredius RG, Puck JM, Stepensky P, Tezcan I, Rolfe K, De Boever E, Reinhardt RR, Appleby J, Ciceri F, Roncarolo MG, Aiuti A. Update on the safety and efficacy of retroviral gene therapy for immunodeficiency due to adenosine deaminase deficiency. Blood 2016; 128 (1): 45-54.

11. De Ravin SS, Reik A, Liu PQ, Li L, Wu X, Su L, Raley C, Theobald N, Choi U, Song AH, Chan A, Pearl JR, Paschon DE, Lee J, Newcombe H, Koontz S, Sweeney C, Shivak 
DA, Zarember KA, Peshwa MV, Gregory PD, Urnov FD, Malech HL. Targeted gene addition in human CD34(+) hematopoietic cells for correction of X-linked chronic granulomatous disease. Nat Biotechnol 2016; 34 (4): 424-429.

12. Deichmann A, Brugman MH, Bartholomae CC, Schwarzwaelder K, Verstegen MM, Howe SJ, Arens A, Ott MG, Hoelzer D, Seger R, Grez M, Hacein-Bey-Abina S, Cavazzana-Calvo M, Fischer A, Paruzynski A, Gabriel R, Glimm H, Abel U, Cattoglio C, Mavilio F, Cassani B, Aiuti A, Dunbar CE, Baum C, Gaspar HB, Thrasher AJ, von Kalle C, Schmidt $\mathrm{M}$, Wagemaker $\mathrm{G}$. Insertion sites in engrafted cells cluster within a limited repertoire of genomic areas after gammaretroviral vector gene therapy. Mol Ther 2011; 19 (11): 20312039.

13. Deichmann A, Hacein-Bey-Abina S, Schmidt M, Garrigue A, Brugman $\mathrm{MH}$, $\mathrm{Hu}$ J, Glimm $\mathrm{H}$, Gyapay G, Prum B, Fraser CC, Fischer N, Schwarzwaelder K, Siegler ML, de Ridder D, Pike-Overzet K, Howe SJ, Thrasher AJ, Wagemaker G, Abel U, Staal FJ, Delabesse E, Villeval JL, Aronow B, Hue C, Prinz C, Wissler M, Klanke C, Weissenbach J, Alexander I, Fischer A, von Kalle C, Cavazzana-Calvo M. Vector integration is nonrandom and clustered and influences the fate of lymphopoiesis in SCID-X1 gene therapy. J Clin Invest 2007; 117 (8): 2225-2232.

14. Desmaris N, Verot L, Puech JP, Caillaud C, Vanier MT, Heard JM. Prevention of neuropathology in the mouse model of Hurler syndrome. Ann Neurol 2004; 56 (1): 68-76.

15. Enquist IB, Nilsson E, Ooka A, Månsson JE, Olsson K, Ehinger M, Brady RO, Richter J, Karlsson S. Effective cell and gene therapy in a murine model of Gaucher disease. Proc Natl Acad Sci USA 2006; 103 (37): 13819-13824.

16. Fuller M, Van der Ploeg A, Reuser AJ, Anson DS, Hopwood JJ. Isolation and characterization of a recombinant, precursor form of lysosomal acid alpha-glucosidase. Eur J Biochem 1995; 234 (3): 903-909.

17. Gaspar HB, Parsley KL, Howe S, King D, Gilmour KC, Sinclair J, Brouns G, Schmidt M, Von Kalle C, Barington T, Jakobsen MA, Christensen HO, Al Ghonaium A, White HN, Smith JL, Levinsky RJ, Ali RR, Kinnon C, Thrasher AJ. Gene therapy of X-linked severe combined immunodeficiency by use of a pseudotyped gammaretroviral vector. Lancet 2004 ; 364 (9452): 2181-2187.

18. Gaspar HB, Cooray S, Gilmour KC, Parsley KL, Adams S, Howe SJ, Al Ghonaium A, Bayford J, Brown L, Davies EG, Kinnon C, Thrasher AJ. Long-term persistence of a polyclonal T cell repertoire after gene therapy for X-linked severe combined immunodeficiency. Sci Transl Med 2011; 3 (97): 97ra79.

19. Gaspar HB, Cooray S, Gilmour KC, Parsley KL, Zhang F, Adams S, Bjorkegren E, Bayford J, Brown L, Davies EG, Veys P, Fairbanks L, Bordon V, Petropoulou T, Kinnon C, Thrasher AJ. Hematopoietic stem cell gene therapy for adenosine deaminase-deficient severe combined immunodeficiency leads to long-term immunological recovery and metabolic correction. Sci Transl Med 2011; 3 (97): 97ra80.
20. Genovese P, Schiroli G, Escobar G, Di Tomaso T, Firrito C, Calabria A, Moi D, Mazzieri R, Bonini C, Holmes MC, Gregory PD, van der Burg M, Gentner B, MontiniE, Lombardo A, Naldini L. Targeted genome editing in human repopulating haematopoietic stem cells. Nature 2014; 510 (7504): 235-240.

21. Gentner B, Visigalli I, Hiramatsu H, Lechman E, Ungari S, Giustacchini A, Schira G, Amendola M, Quattrini A, Martino S, Orlacchio A, Dick JE, Biffi A, Naldini L. Identification of hematopoietic stem cell-specific miRNAs enables gene therapy of globoid cell leukodystrophy. Sci Transl Med 2010; 2 (58): $58 \mathrm{ra} 84$.

22. Hacein-Bey-Abina S, Hauer J, Lim A, Picard C, Wang GP, Berry CC, Martinache C, Rieux-Laucat F, Latour S, Belohradsky BH, Leiva L, Sorensen R, Debré M, Casanova JL, Blanche S, Durandy A, Bushman FD, Fischer A, Cavazzana-Calvo M. Efficacy of gene therapy for X-linked severe combined immunodeficiency. N Engl J Med 2010; 363 (4): 355-364.

23. Hacein-Bey-Abina S, Pai SY, Gaspar HB, Armant M, Berry CC, Blanche S, Bleesing J, Blondeau J, de Boer $\mathrm{H}$, Buckland KF, Caccavelli L, Cros G, De Oliveira S, Fernández KS, Guo D, Harris CE, Hopkins G, Lehmann LE, Lim A, London WB, van der Loo JC, Malani N, Male F, Malik P, Marinovic MA, McNicol AM, Moshous D, Neven B, Oleastro M, Picard C, Ritz J, Rivat C, Schambach A, Shaw KL, Sherman EA, Silberstein LE, Six E, Touzot F, Tsytsykova A, Xu-Bayford J, Baum C, Bushman FD, Fischer A, Kohn DB, Filipovich AH, Notarangelo LD, Cavazzana M, Williams DA, Thrasher AJ. A modified $\gamma$-retrovirus vector for X-linked severe combined immunodeficiency. N Engl J Med 2014; 371 (15): 1407-1417.

24. Hoogerbrugge PM, Suzuki K, Suzuki K, Poorthuis BJ, Kobayashi T, Wagemaker G, van Bekkum DW. Donor-derived cells in the central nervous system of twitcher mice after bone marrow transplantation. Science 1988; 239 (4843): 1035-1038.

25. Hoogerbrugge PM, Wagemaker G, van Bekkum DW, Reuser AJ, vd Ploeg AT. Bone marrow transplantation for Pompés disease. N Engl J Med 1986; 315 (1): 65-66.

26. Huston MW, Riegman AR, Yadak R, van Helsdingen Y, de Boer H, van Til NP, Wagemaker G. Pretransplant mobilization with granulocyte colony-stimulating factor improves B-cell reconstitution by lentiviral vector gene therapy in SCID-X1 mice. Hum Gene Ther 2014; 25 (10): 905-914.

27. Kaufmann KB, Chiriaco M, Siler U, Finocchi A, Reichenbach J, Stein S, Grez M. Gene therapy for chronic granulomatous disease: current status and future perspectives. Curr Gene Ther 2014; 14 (6): 447-460.

28. Kustikova OS, Geiger H, Li Z, Brugman MH, Chambers SM, Shaw CA, Pike-Overzet K, de Ridder D, Staal FJ, von Keudell G, Cornils K, Nattamai KJ, Modlich U, Wagemaker G, Goodell MA, Fehse B, Baum C. Retroviral vector insertion sites associated with dominant hematopoietic clones mark "stemness" pathways. Blood 2007; 109 (5): 1897-1907.

29. Naldini L, Blömer U, Gallay P, Ory D, Mulligan R, Gage FH, Verma IM, Trono D. In vivo gene delivery and stable transduction of nondividing cells by a lentiviral vector. Science 1996; 272 (5259): 263-267. 
30. Pala F, Morbach H, Castiello MC, Schickel JN, Scaramuzza S, Chamberlain N, Cassani B, Glauzy S, Romberg N, Candotti F, Aiuti A, Bosticardo M, Villa A, Meffre E. Lentiviral-mediated gene therapy restores $\mathrm{B}$ cell tolerance in Wiskott-Aldrich syndrome patients. J Clin Invest 2015; 125 (10): 3941-3951.

31. Pike-Overzet K, de Ridder D, Weerkamp F, Baert MR, Verstegen MM, Brugman MH, Howe SJ, Reinders MJ, Thrasher AJ, Wagemaker G, van Dongen JJ, Staal FJ. Gene therapy: is IL2RG oncogenic in T-cell development? Nature 2006; 443 (7109): E5; discussion E6-7.

32. Pike-Overzet $\mathrm{K}$, van der Burg $\mathrm{M}$, Wagemaker $\mathrm{G}$, van Dongen JJ, Staal FJ. New insights and unresolved issues regarding insertional mutagenesis in X-linked SCID gene therapy. Mol Ther 2007; 15 (11): 1910-1916.

33. Pompe JC. Over idiopathische hypertrophie van het hart. 1932; N. T. v. G. 76.I.3.

34. Rivera-Munoz P, Abramowski V, Jacquot S, André $\mathrm{P}$, Charrier S, Lipson-Ruffert K, Fischer A, Galy A, Cavazzana $M$, de Villartay JP. Lymphopoiesis in transgenic mice over-expressing Artemis. Gene Ther 2016; 23 (2): 176-186.

35. Rocha V, Wagner JE Jr, Sobocinski KA, Klein JP, Zhang MJ, Horowitz MM, Gluckman E. Graft-versus-host disease in children who have received a cord-blood or bone marrow transplant from an HLA-identical sibling. Eurocord and International Bone Marrow Transplant Registry Working Committee on Alternative Donor and Stem Cell Sources. N Engl J Med 2000; 342 (25): 1846-1854.

36. Schambach A, Bohne J, Baum C, Hermann FG, Egerer L, von Laer D, Giroglou T. Woodchuck hepatitis virus post-transcriptional regulatory element deleted from $\mathrm{X}$ protein and promoter sequences enhances retroviral vector titer and expression. Gene Ther 2006; 13 (7): 641-645.

37. Schwarzwaelder K, Howe SJ, Schmidt M, Brugman MH, Deichmann A, Glimm H, Schmidt S, Prinz C, Wissler M, King DJ, Zhang F, Parsley KL, Gilmour KC, Sinclair J, Bayford J, Peraj R, Pike-Overzet K, Staal FJ, de Ridder D, Kinnon C, Abel U, Wagemaker G, Gaspar HB, Thrasher AJ, von Kalle C. Gammaretrovirus-mediated correction of SCID-X1 is associated with skewed vector integration site distribution in vivo. J Clin Invest 2007; 117 (8): 2241-2249.

38. Shou Y, Ma Z, Lu T, Sorrentino BP. Unique risk factors for insertional mutagenesis in a mouse model of XSCID gene therapy. Proc Natl Acad Sci USA 2006; 103 (31): 11730-11735.

39. van den Hout HM, Hop W, van Diggelen OP, Smeitink JA, Smit GP, Poll-The BT, Bakker HD, Loonen MC, de Klerk JB, Reuser AJ, van der Ploeg AT. The natural course of infantile Pompe's disease: 20 original cases compared with 133 cases from the literature. Pediatrics 2003; 112 (2): 332-340.
40. van der Ploeg AT, Reuser AJ. Pompe's disease. Lancet 2008 Oct 11; 372 (9646): 1342-53.

41. van Gelder CM, Hoogeveen-Westerveld M, Kroos MA, Plug I, van der Ploeg AT, Reuser AJ. Enzyme therapy and immune response in relation to CRIM status: the Dutch experience in classic infantile Pompe disease. J Inherit Metab Dis. 2015; 38 (2): 305-314.

42. van Til NP, Wagemaker G. Lentiviral gene transduction of mouse and human hematopoietic stem cells. Methods Mol Biol 2014; 1185: 311-319.

43. Visigalli I, Delai S, Politi LS, Di Domenico C, Cerri F, Mrak E, D'Isa R, Ungaro D, Stok M, Sanvito F, Mariani E, Staszewsky L, Godi C, Russo I, Cecere F, Del Carro U, Rubinacci A, Brambilla R, Quattrini A, Di Natale P, Ponder K, Naldini L, Biffi A. Gene therapy augments the efficacy of hematopoietic cell transplantation and fully corrects mucopolysaccharidosis type I phenotype in the mouse model. Blood 2010; 116 (24): 5130-5139.

44. Visigalli I, Delai S, Ferro F, Cecere F, Vezzoli M, Sanvito F, Chanut F, Benedicenti F, Spinozzi G, Wynn R, Calabria A, Naldini L, Montini E, Cristofori P, Biffi A. Preclinical testing of the safety and tolerability of LV-mediated above normal alpha-L-iduronidase expression in murine and human hematopoietic cells using toxicology and biodistribution GLP studies. Hum Gene Ther 2016 Jul 18.

45. Wagemaker G. Lentiviral hematopoietic stem cell gene therapy in inherited metabolic disorders. Hum Gene Ther 2014; 25 (10): 862-865.

46. Walia JS, Neschadim A, Lopez-Perez O, Alayoubi A, Fan X, Carpentier S, Madden M, Lee CJ, Cheung F, Jaffray DA, Levade T, McCart JA, Medin JA. Autologous transplantation of lentivector/acid ceramidase-transduced hematopoietic cells in nonhuman primates. Hum Gene Ther 2011; 22 (6): 679-687.

47. Yoshimitsu M, Higuchi K, Ramsubir S, Nonaka T, Rasaiah VI, Siatskas C, Liang SB, Murray GJ, Brady RO, Medin JA. Efficient correction of Fabry mice and patient cells mediated by lentiviral transduction of hematopoietic stem/progenitor cells. Gene Ther 2007; 14 (3): 256-265.

48. Zhang F, Thornhill SI, Howe SJ, Ulaganathan M, Schambach A, Sinclair J, Kinnon C, Gaspar HB, Antoniou M, Thrasher AJ. Lentiviral vectors containing an enhancer-less ubiquitously acting chromatin opening element (UCOE) provide highly reproducible and stable transgene expression in hematopoietic cells. Blood. 2007; 110 (5): 1448-1457. 


\section{| Генная терапия лентивирусными векторами в гемо- поэтических стволовых клетках при врожденных дефицитах иммунитета и лизосомных энзимов}

\section{Герард Вагемакер}

Университет Эразмус, Роттердам, Нидерланды; Центр исследования и разработки стволовых клеток, Университет Хашеттепе, Анкара, Турция; НИИ детской онкологии, гематологии и трансплантологии им. Р. М. Горбачевой, Первый Санкт-Петербургский государственный медицинский университет им. И. П. Павлова, Санкт-Петербург, Россия

\section{Резюме}

Редкие болезни поражают, в целом, миллионы людей во всем мире. Многие из этих являются наследственными заболеваниями, ведущими к инвалидности и требующими дорогостоящего ухода. Генная терапия гемопоэтическими стволовыми клетками (ГТГСК) разработана за последние 20 лет. На современном уровне генная терапия выполнима при заболеваниях, для которых (1) есть идентифицированный генетический дефект, (2) диагноз ставится достаточно рано для действенного терапевтического вмешательства, (3) имеется специфическая экспериментальная модель для оценки эффективности и безопасности лечения. Соответствующие терапевтические трансгены должны также отвечать определенным биологическим критериям. Лентивирусные векторы третьего поколения выполнены самоинактивирующимися (SIN), путем делеции энхансерных участков из LTR-последовательностей, тем самым снижая риск воздействия на соседние гены, что приводит к достаточным уровням безопасности. В настоящее время лентивирусная ГТГСК вступила в фазу начального клинического внедрения для лечения иммунодефицитов и лизосомных болезней накопления. Мы обсуждаем начальные клинические испытания с применением этих векторов для некоторых метаболических болезней накопления, которые включают адренолейкодистрофию, метахроматическую лейкодистрофию, синдром Гурлер (MPS I), Помпе (GSD II), и болезнь Фабри. Данный краткий обзор обобщает развитие и современное клиническое внедрение этих подходов.

\section{Ключевые слова}

Гемопоэтические стволовые клетки, лентивирусный вектор, генная терапия, врожденные иммунодефициты, лизосомные болезни. 